\title{
Two new species of Erica (Ericaceae); one from Western Cape and one from KwaZulu-Natal, South Africa
}

\author{
E.G.H. OLIVER* and I.M. OLIVER*广
}

Keywords: Erica L.. KwaZulu-Natal. new species, South Africa. taxonomy. Western Cape

\section{ABSTRACT}

\begin{abstract}
Two new species of Erica L. from South Africa are described. $E$. jananthus E.G.H.Oliv. \& I.M.Oliv. is confined to a single peak in the eastern Groot Swartherg Range in Western Cape and usually forms a small. gnarled. woody, shrublet growing in rock crevices with sticky white flowers and black subexserted anthers that have obtrullate decurrent appendages. E. psittacina E.G.H.Oliv. \& I.M.Oliv. is from KwaZulu-Natal. It forms large woody shrubs with numerous bright pink flowers and occurs as a single population on a mountain near Creighton. Both descriptions are accompanied by line drawings and distribution maps
\end{abstract}

1. Erica jananthus E.G.H.Oliv: \& I.M.Oliv., sp nov.. fruticulo plerumque parvo lignoso plectile. foliis 3natis, foliis bractea bracteolis sepalibusque glandibus marginalibus sessilibus fulvis ad brunneis, corolla urceolata viscida lobis effusis ad recurvatis, antheris 8 subexsertis calcaribus decurrentibus anguste ad equilateriliter obtrullatis et irregulatiter denticulatis, ovario villoso 4-loculare ovulis 6-8. seminibus parietibus anticlinalibus percrassis dignoscenda. Figura 1 .

TYPE.-Western Cape, 3322 (Oudtshoorn): Great Swartberg, eastern end, Snyberg, peak just WNW of beacon, $1570 \mathrm{~m},(-\mathrm{BD}), 16$ November 2(0)1. Oliver $1 / 986$ (NBG, holo.: BM, K. MO, NY. PRE).

Shrublet compact to loose. $20 \times 30-100 \times 150 \mathrm{~mm}$. usually woody, single-stemmed. Branches: numerous main branches $\pm 10 \mathrm{~mm}$ long. leafy with occasional leafy side branchlets $2-5 \mathrm{~mm}$ long: stems puberulous to sparsely strigose with some glands admixed. Leaves 3nate. erect-spreading to patent, elliptic to narrowly lanceolate, $1.5-1.7 \times 0.5-0.7 \mathrm{~mm}$. rounded to flattened adaxially and rounded abaxially, sparsely puberulous on both surfaces to almost glabrous adaxially, sulcus narrow and open at base, margins rounded with yellowish to pale brown sessile glands and one apical gland. often completely glabrous when older: petiole adpressed. (0.4-0.5 $\mathrm{mm}$ long. edged with short hairs and subsessile to sessile glands. Inflorescence: 1-3 flowers in a single whorl at ends of leafy. short, main branches and occasional lateral branchlets, the latter sometimes aggregated at ends of main branches; pedicel $\pm 2.4 \mathrm{~mm}$ long. sparsely and shortly strigulose with longer and stouter gland-tipped hairs or sessile glands admixed: bract partially recaulescent in lower quarter of pedicel. elliptic. $\pm 0.9 \times 0.5 \mathrm{~mm}$. sparsely puberulous ciliate with yellowish to pale brown sessile glands. white sometimes tinged green: bracteoles 2 in mid position, slightly obovate. otherwise like bract. Calyx 4-partite: lobes adpressed to corolla. elliptic to

\footnotetext{
* Compton Herbarium. National Botanical Institute. Private Bag X7. 7735 Claremont. Cape Town.

+ obiit 6-(1)7-200)3

MS. received: $2(\times) 3-(1) 8-(1) 8$.
}

broadly so, $\pm 1.5 \times 1.0-1.2 \mathrm{~mm}$, glabrous, edged with numerous sessile glands, white with narrowly sulcate green apex. Corolla 4 -lobed, globose urceolate, $\pm 3.0 \times$ $2.5 \mathrm{~mm}$. glabrous, viscid, white: lobes broadly ovate, \pm 1 $\times 1.5-2.0 \mathrm{~mm}$, spreading to recurved, obtuse or emarginate, minutely and irregularly toothed. Stamens 8 , free; filaments $1.8-2.0 \times 0.2-0.3 \mathrm{~mm}$. linear, curved, glabrous; anthers subexserted, bilobed appendiculate. thecae $\pm 0.7 \times 0.3 \mathrm{~mm}$ and oblong in adaxial view. \pm 0.8 $\times 0.4 \mathrm{~mm}$ and elliptic in lateral view, golden brown to red-brown, pore $\pm 1 / 2$ length of theca, appendages decurrent on filament, $\pm 0.3 \times 0.2 \mathrm{~mm}$, narrowly to equilaterally obtrullate, pendulous, irregularly denticulate, pale brown to cream-coloured: pollen shed in tetrads. Ovary 4-locular, globose to depressed globose. $(0.5-0.9 \times 0.9$ $\mathrm{mm}$, obtuse to almost flat apically, villous, white to pale green, with well-developed, dark nectaries around base; ovules 6-8 per locule, pendulous from apical placenta: style exserted, narrowly cylindric. slightly curved. \pm 3 $\mathrm{mm}$ long. white, glabrous; stigma simple-truncate to slightly capitellate, dark green. Fruit a dehiscent capsule $\pm 1.9 \times 2.6 \mathrm{~mm}$, valves opening full length. septa equal on valves and columella. Seeds \pm ellipsoid, $\pm 0.7 \times 0.35$ $\mathrm{mm}$. sometimes curved. with flattened micropilar end; testa alveolate, cells $\pm 100 \times 16-20 \mu \mathrm{m}$, anticlinal walls unequally undulate and considerably thickened. periclinal walls with scattered pits. Figure 1 .

Diagnostic features: small, woody, gnarled shrublet: leaves 3-nate; leaves, bract, bracteoles and sepals edged with yellow to brown sessile glands; corolla urceolate. viscid white with spreading to recurved lobes: anthers 8 subexserted with appendages decurrent on filament, narrowly to equilaterally obtriangular and irregularly denticulate; ovary 4-locular with 6-8 ovules per locule, villous; seeds with considerably thickened, unequally undulate, anticlinal walls.

Erica janamthus is an isolated species with no clear indications of its relationships. With the 3-nate leaves, marginal glands on the bract, bracteoles and sepals producing a viscid corolla, it would appear to lie within the group in $\$ P a c h y s a$ that has several species frequenting the mountains in and around the Little Karoo- $E$. formosa Thunb., E. spectabilis Klotzsch ex Benth., E. trag- 


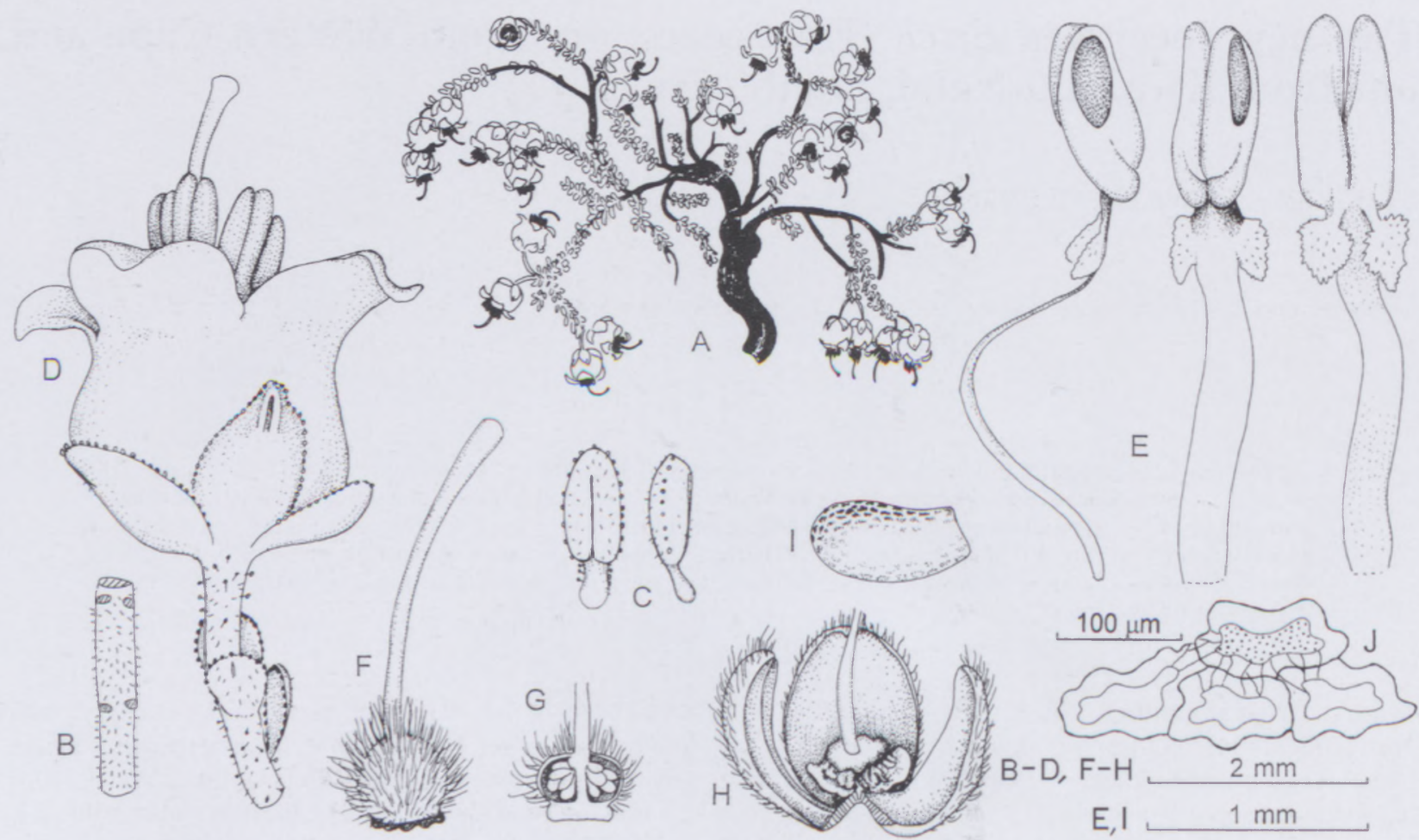

FIGURE 1.-Erica jananthus. A, flowering branch, natural size; B, stem; C, leaf, back and lateral views; D, flower; E, stamen, lateral, front and back views; F, gynoecium; G, ovary, opened laterally to show placentation; H, capsule with one valve removed; I, seed; J, testa cells. All drawn from the type, Oliver 11986. Scale bars: B-D, F-H, 2 mm; E, I, 1 mm; J, $100 \mu \mathrm{m}$. Artist: Inge M. Oliver.

ulifera Salisb., E. glomiflora Salisb., E. zwartbergensis Bolus, E. andreaei Compton. In those species, however, the anthers are very different with their long thick hairs and narrower appendages, although the latter are often decurrent along the upper part of the filament, and villous ovary. We recently described $E$. dolfiana E.G.H.Oliv. (Oliver \& Oliver 2001) from the nearby Blesberg. It has marginal glands on the above-mentioned organs but these are stalked and dark red.

This new species was brought to our attention by the botanist, Jan Vlok of Oudtshoorn, when doing a survey of that part of the Groot Swartberg. The epithet for this new species recognizes his considerable contribution to the recording of plant species and distributions in the mountains surrounding the Little Karoo, jananthus = Jan's flower (Latin), there already being $E$. vlokii E.G.H.Oliv. from the Meiringspoort, Kammanassie and
Herold areas (Oliver 2000). We have described several new species of Erica from the Swartberg in the Meiringspoort area: $E$ dolfiana E.G.H.Oliv., E. ingeana E.G.H.Oliv., E. vlokii E.G.H.Oliv., E. lithophila E.G.H.Oliv. \& I.M.Oliv., E. jugicola E.G.H.Oliv. \& I.M.Oliv. and E. umbratica E.G.H.Oliv. \& I.M.Oliv.

The species is as far as we know confined to the Snyberg peaks in the eastern part of the Groot Swartberg Range east of Meiringspoort (Figure 2). There it grows only in rock crevices on south-facing, small, rocky ridges and outcrops in shade for most of the day. A single plant growing in the ground at the base of one ridge was more shrubby, thinner stemmed and up to $300 \mathrm{~mm}$ tall. The species does not occur further west on the peaks around Blesberg but there are several peaks to the east of Snyberg that have never been explored botanically.

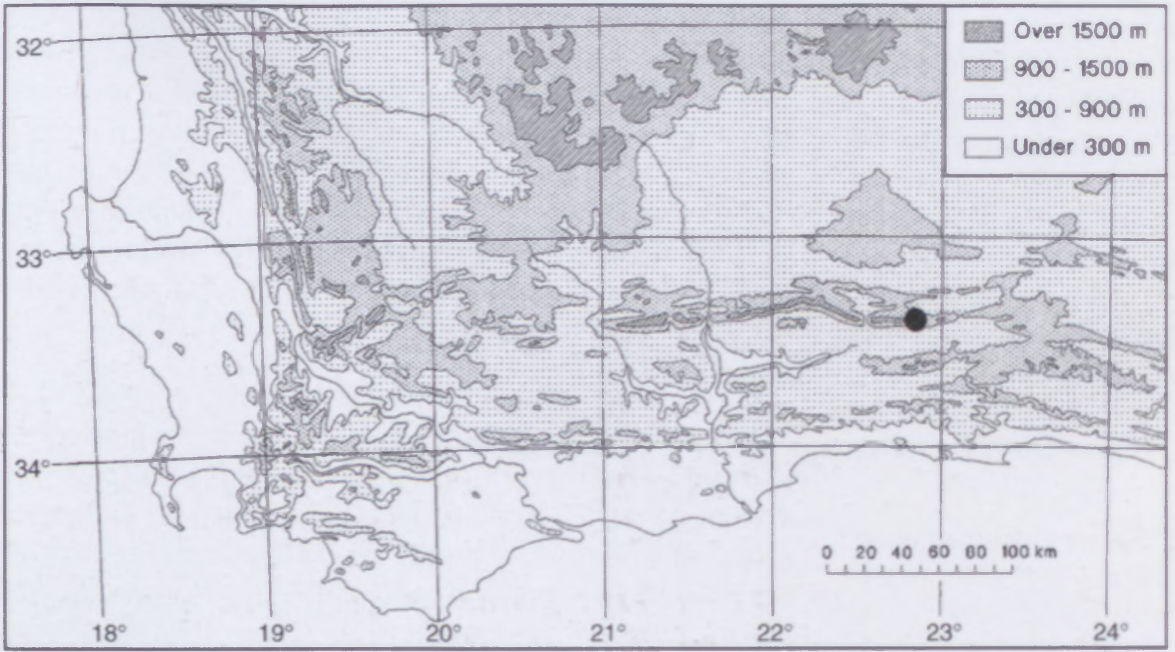

FIGURE 2.-Known distribution of Erica jananthus. 


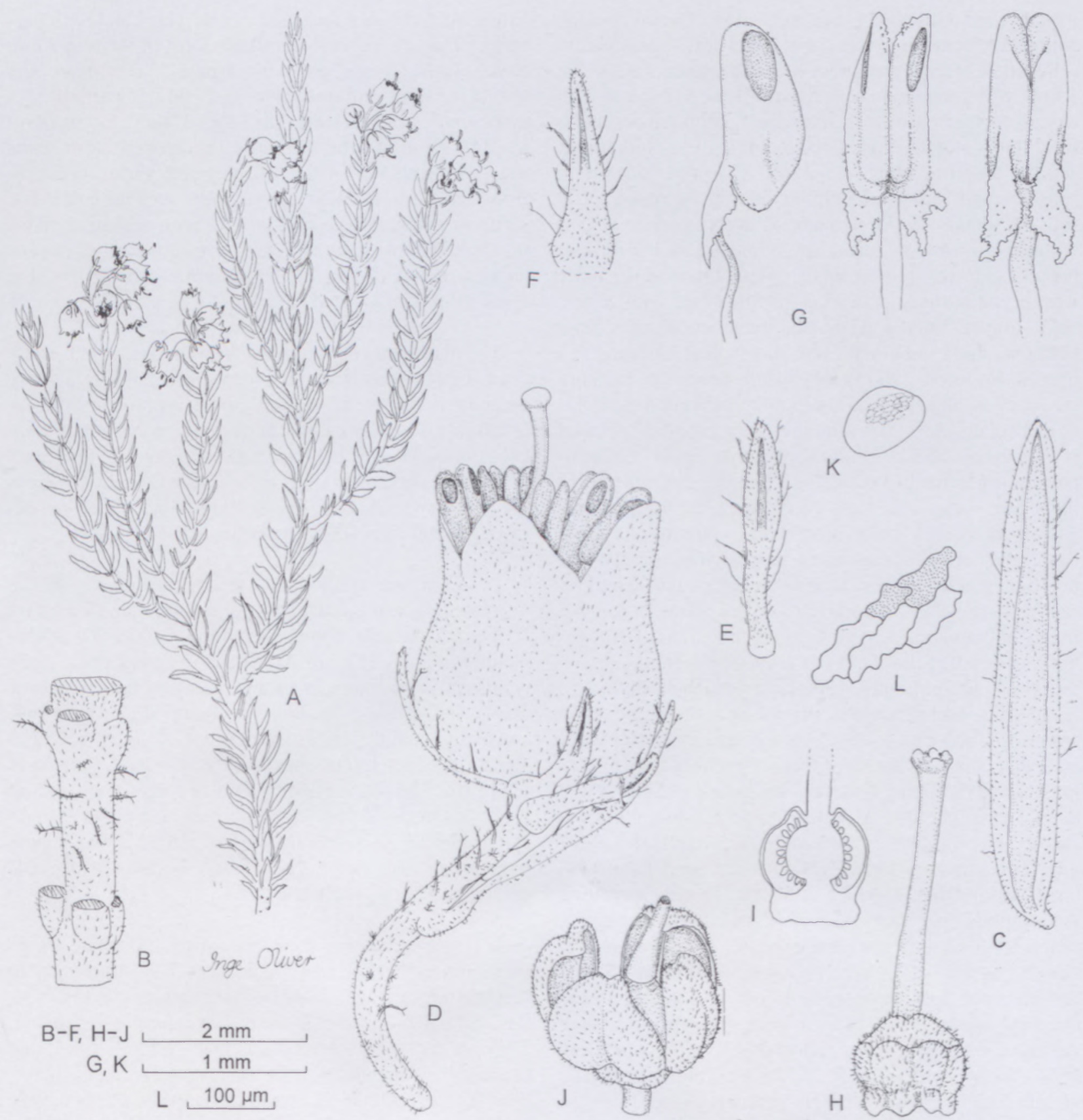

FIGURE 3.-Erica psittacina. A, flowering branch, natural size; B, stem with leaves removed; C, leaf; D, flower; E, bracteole; F, sepal; G, anther, lateral, front and back views; H. gynoecium; I, ovary, 1/s showing placenta and ovule positions; J, capsule; $\mathrm{K}$, seed; L, testa cells. All drawn from the type, Oliver \& Turner 12167. Scale bars: B-F, H-J, 2 mm; G, K, 1 mm; L, $100 \mu \mathrm{m}$. Artist: Inge Oliver.

No pollinators were noted when the type collection was made. Pollination is presumed to be carried out by flying insects because of the presence of nectaries and the reduced size of the stigma. Crawling insects would encounter problems with the viscid corolla.

\section{Paratype material}

WESTERN CAPE_-3322 (Oudtshoom): Great Swartberg Mtns, Snyberg, 1500 m, (-BD), 22-08-1990, Vlok 2377 (NBG); ibid., 11-03-1991. fruiting, Vlok 2453 (NBG); ibid., 12-11-1991, Vlok 2533 (NBG, PRE).

2. Erica psittacina E.G.H.Oliv. \& I.M.Oliv., sp. nov., frutice magno lignoso ad $2 \mathrm{~m}$ raro $3 \mathrm{~m}$ alto unicauli, foliis 4-natis, inflorescentibus parte inferiore racemosa superiore umbelliformi, corolla subtiliter breviterque pubescenti clarorosea, indumento in partibus multis pilis brevissimis cum pilis paucis crassis plumosis apice furcato dignoscenda. Figura 3.

TYPE.-KwaZulu-Natal, 2929 (Underberg): Creighton, Hlabeni, steep southeast-facing slopes below summit ridge, 1662 m, (-DC), 4 February 2003, Oliver \& Turner 12167 (NBG, holo.; BM, CPF, K, NH, NU, NY, PRE).

Shrub woody, bushy, erect, 1.0-1.5(-2.0)[-3.0] m tall, single-stemmed. Branches: main branches up to $400 \mathrm{~mm}$ long, sometimes topped with numerous vegetative secondary branches or just flowering secondary branches; secondary branches numerous, $100-160 \mathrm{~mm}$ long, with 1 or 2 tertiary branches $30-60 \mathrm{~mm}$ long; stem with dense, short, simple hairs and spreading to reflexed, stouter, longer hairs admixed, these mostly shortly plumose mainly towards base of hair and sometimes with longer 
forked tips; internodes 2-5 mm long. Leaves 4-nate, suberect to spreading but curved upwards, occasionally reflexed at base of secondary branches, lanceolate, $\pm 7 \times$ $1 \mathrm{~mm}$, with rounded margins, partially open-backed with sulcus open at base, with fine, short, simple hairs and a few, long, stouter, fork-tipped hairs, these sometimes shortly plumose at base; petiole $\pm 1 \mathrm{~mm}$ long, with sparse, short, simple hairs; on margins a few shortly stalked glands. Inflorescence: flowers 4-nate in 2-5 whorls, terminal on secondary branches, rarely tertiary branches, lower 1 or 2 whorls with internodes, upper whorls umbel-like; pedicel 4-6 mm long, with dense, fine, simple hairs and sparse, long, stout, spreading, plumose hairs admixed, red; bract leaf-like and on branch in lower whorls of inflorescence to partially recaulescent in mid position in upper whorls; bracteoles 2 , lanceolate, $\pm 3 \times 0.4 \mathrm{~mm}$, green, base pinkish, placed $\pm 2 / 3$ way up pedicel, indumentum like bract. Calyx 4 partite; segments lanceolate, $\pm 2.5-3.0 \times 0.5 \mathrm{~mm}$, finely hairy plus long, stout hairs on margins, the upper terminally forked, the lower also shortly plumose towards base, acute or attenuated into a long, plumose seta; upper half of segments green, lower pink, sulcus $\pm 1 / 2$ length of segment. Corolla 4-lobed, globose-urceolate, $\pm 4 \times 3.5$ $\mathrm{mm}$, finely puberulous, pink; lobes suberect, $\pm 0.8 \times 1.5$ $\mathrm{mm}$, rounded, entire. Stamens 8 , manifest; filaments \pm 3 $\mathrm{mm}$ long, straight; anthers basifixed, bilobed, oblong in front view, appendiculate, orange-brown; thecae erect adpressed, oblong, $\pm 1.0-1.3 \times 0.5 \mathrm{~mm}$ in lateral view, aculeate, pore $\pm 1 / 2$ length of theca, appendages $\pm 0.7 \mathrm{~mm}$ long, \pm ovate-elliptic, flattened, irregularly shallowly and deeply toothed, yellow; pollen in tetrads. Ovary 4-locular, depressed globose-obovoid, emarginate, $\pm 1.2 \times 1.5$ $\mathrm{mm}$, covered with simple, short hairs, with large nectaries around base; ovules \pm 50 per locule, spreading from bulbous placenta on upper $2 / 3$ of columella; style \pm $4 \mathrm{~mm}$ long, exserted; stigma capitate. Fruit a dehiscent capsule, $\pm 1.8 \times 2.3 \mathrm{~mm}$, valves spreading to $45^{\circ}$ but curved-erect, split to base, septa only on valves. Seeds ellipsoid-ovoid, $\pm 0.5 \times 0.25 \mathrm{~mm}$, sometimes angled, very shallowly alveolate, yellow-brown to brown; testa cells oblong, $\pm 50-100 \times 25-35 \mu \mathrm{m}$, anticlinal walls undulate to irregularly slightly jigsawed, slightly thickened, periclinal walls finely pitted. Figure 3.

Diagnostic features: large, woody, single-stemmed shrub, mostly $1.0-1.5$, occasionally up to 2 , rarely $3 \mathrm{~m}$ tall; leaves 4-nate; flowers in inflorescences of racemose lower and umbel-like upper whorls; bract leaf-like and non-recaulescent in lowest whorls to reduced and partially recaulescent in the middle position in the uppermost whorls; corolla finely and shortly hairy, bright pink; indumentum on stems, leaves, pedicel, bract, bracteoles and sepals finely and densely hairy with simple hairs and some long, stout hairs admixed, these shortly and sometimes densely plumose, mainly towards the base and often with longer, forked tips.

Erica psittacina is a very distinct species among the 32 Erica species that occur in KwaZulu-Natal. Its relationships with these species is not clear. Within the group of species having 4-nate leaves, it is perhaps most similar to $E$. algida Bolus which is widespread along the whole Drakensberg Range but that differs in being a multi-stemmed resprouter, and having the flowers in a single inflorescence arranged in one whorl and with partially recaulescent bract. Similarly most of the remaining KwaZulu-Natal species with 4-nate leaves have the wrong type of inflorescence and only a partially recaulescent bracts. However, the 4-nate E. revoluta L.E.Davidson has the racemose inflorescence but without the terminal umbel and the bract varies similarly from its axial position to partially recaulescent. The shrub is usually large and woody with a similar indumentum in most parts and the leaves are partially openbacked, but it differs in the glabrous corolla, and the reduced, partially fused calyx.

The plants are very vigorous growers. With old flowers from the previous flowering season often still remaining on some branches, the annual growth increment is easily assessable. In many cases it is as much as $200 \mathrm{~mm}$, rarely to $300 \mathrm{~mm}$. This characteristic is reminiscent of the plants in the type population of E. oakesiorum E.G.H.Oliv. from Western Cape (Oliver \& Oliver 1996) in which the growth can be as much as $400 \mathrm{~mm}$ in one season.

E. psittacina is the most restricted species in the province, occurring only in a remarkably small area on Hlabeni Mountain above Creighton in the KwaZuluNatal Midlands (Figure 4). There it grows on a steep southeast-facing slope in a long, relatively narrow belt of dense, indigenous, shrubby vegetation up to $4 \mathrm{~m}$ tall, consisting mainly of Tarchonanthus camphoratus and along the upper limits, species of Passerina, Protea and Cliffortia. The slope is composed of large boulders and rocky outcrops. Below that belt there is a pristine stand of tall indigenous forest above vast tracts of exotic pine plantations. The summit of Hlabeni is covered in wellgrazed and burnt, short grassland.

It is estimated that there are up to 100 plants of $E$. psittacina in this extended population. The shrubs vary in height from $1 \mathrm{~m}$ tall in more exposed open places to almost $2 \mathrm{~m}$ tall and rarely taller in the denser stands of vegetation. They are mostly scattered plants that are easily noted due to their abundant pink flowers contrasting against the otherwise drab vegetation. Access to many of the plants is very difficult due to the nature of the terrain and density of the vegetation. In those that could be examined closely it was

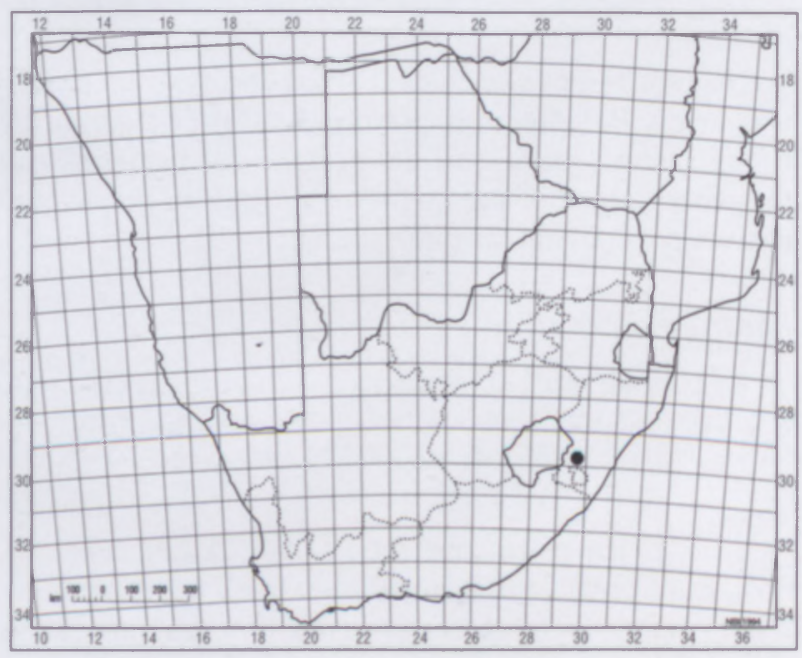

FIGURE 4.-Known distribution of Erica psittacina. 
noted that the plants are single-stemmed with a trunk up to $100 \mathrm{~mm}$ in diameter. The vegetation appeared to be very old and not affected by the frequent fires that must sweep the summit plateau, perhaps being protected by a wind shadow. From below, the habitat is protected by the dense. tall belt of indigenous forest.

The flowers were seen to be visited by a few honey bees. This corresponds with large nectaries around the base of the ovary, the exserted stigma which with slightly enlarged and the partially exserted anthers, in strongly suggesting an insect pollination syndrome for the species. A slight scent was noticeable from the fresh flowers in the wild. It was, however, not possible to see whether the bees came for nectar or just pollen.

The epithet for this new species honours the very distinguished and rare inhabitant of Hlabeni, the Cape parrot, Poicephalus robustus (psittacinus = belonging to, possession of, the parrot). The plants were discovered there by our daughter and two molecular systematists from Stellenbosch University who were visiting the mountain in $20(02$ to sample the orchids. The indigenous forests above which the erica grows is inhabited by a remnant population of Cape parrots. It was through the assistance of the local conservationist and parrot enthusiast.
Malcolm Gemmel, that they and ourselves visited the mountain.

\section{Paratype material}

KWAZULU-NATAL.-2929 (Underberg): Creighton. Hlabeni. \pm 1 680 m. (-DC). 24-01-2002. T.A.Oliver 8 (NBG)

\section{ACKNOWLEDGEMENTS}

We wish to thank Jan Vlok of Oudtshoorn and Malcolm Gemmel of Creighton for their valued assistance in the field. The Western Cape Nature Conservation Board is thanked for granting us permission to collect plants in Western Cape.

\section{REFERENCES}

OLIVER. E.G.H. 2000. Systematics of Ericeae (Ericaceae: Ericoideae): species with indehiscent and partially dehiscent fruits. Contributions from the Bolus Herbarium 19:345.

OLIVER. E.G.H. \& OLIVER. I.M. 1996. Studies in the Ericeae (Ericoideae), XX. A rare new species of Erica from South Africa. Yearbook of the Heather Socien 1996: 1-5.

OLIVER, E.G.H. \& OLIVER, I.M. 2001. Five new species of Erica (Ericaceae) from the Swartberg Range. Western Cape, South Africa and a note on E. esterhurseniae. Bothalia 31: 155-165. 